\title{
Travel by Ship in the Late Middle Ages - Felix Fabri's Pilgrimage Account as a Meticulous Eye-Witness Report
}

\author{
Albrecht Classen* \\ University of Arizona, US
}

*Corresponding Author: Albrecht Classen, University of Arizona, US

\begin{abstract}
The late medieval Dominican friar/priest Felix Fabri from Ulm, Germany, is famous for his extensive travelogues about his pilgrimages to the Holy Land, and for some other instructive texts. Previous scholars have mostly focused on the themes of travel, the encounter with the foreign, Arab and Muslim, world, and religious experiences of a Christian traveler. This paper turns to his amazingly thorough discussion of daily experiences on a ship with pilgrims on their way to Palestine, addressing basic aspects such as sleeping quarters, toilets, sickness, foodstuff, vermin, clothing, lack of hygiene, and sea-sickness. Fabri's Evagatorium proves to be an extraordinary late medieval narrative that conveys fundamental information about everyday life during a voyage.
\end{abstract}

Keywords: Felix Fabri, Voyage to the Holy Land, Practical Aspects of a Voyage, Medieval Entertainment, Eating Habits, Pleasure and Leisure, Illness, Reading, Bodily Functions, Attitudes.

\section{INTROduCtion: TRAVEL IN THE MidDle AgeS}

Many times, historical documents and literary narratives give us only general information about the actual conditions on the ground. We learn, for instance, that in the Middle Ages groups of knights, merchants, clerics, pilgrims, and many others commonly traveled over land or used ships to reach their goals. We are told, perhaps, how many days it took to reach the goal, but further details escape us. The narrators relate when they departed, what major cities they touched on their route, how long the voyage or travel lasted, and then they immediately turn to other aspects unrelated to the travel itself. However, there is hardly any information about how the travelers found their way without the use of detailed maps or a compass, about where they stayed at night, how they financed their trip, how they overcame linguistic problems, what kind of food they consumed, how they cleaned their clothes, or whether they were attacked by robbers, abused by toll officials, hassled by other authority figures, about whether they were plagued by vermin, insects, or were attacked by wild animals, or whether they suffered from sickness, hunger, and thirst.

\section{Medieval Sources on Travel}

Only recently has new research sharpened our focus on the historical sources, so we can now say much more about food consumption, travel conditions, linguistic challenges, geographic knowledge, and so forth (Stabel and Baatsen; Classen, ed.). We have increasingly turned to pre-modern travelogues that easily prove to be highly expressive and most meaningful documents reflecting on the actual day-to-day conditions, allowing us to comprehend the ordinary situation in real conditions (Alltagsgeschichte), and this, quite understandably, much better than romances or heroic epics, even if some of the medieval poets focus on many different travel experiences (Dorninger). The pilgrims in Chaucer's Canterbury Tales (ca. 1400) do not say anything about the conditions on the road; the mystical writer Margery Kempe (ca. 1378-ca. 1438) relates much about her religious experiences on her major pilgrimages to Rome, Jerusalem, Santiago de Compostella, and Wiesneck, but her focus rests primarily on the religious dimensions. Konrad Grünemberg, who traveled to the Holy Land in 1486, goes so far as to describe the ship at great length, but then his attention turns to the individual sites on their voyage, examining the various churches or holy locations (Denke). Arnold von Harff (1471-1505), who traveled to the Holy Land from 1496 to 1498, explicitly emphasizes that he must refrain from going into all the details about the dangers and adventures that he had to face and that he would limit himself to the discussion of the major cities and ports (Harff, 89). Other pilgrimage authors pursue exclusively the goal of guiding their readers from one holy site to the other and demonstrate no interest in the daily matters (Brefeld). 
From early on, medieval literature knows of many travel narratives, whether we think of the Old Irish accounts of Saint Brendan, the late antique Apollonius of Tyrus, the many different versions of Tristan and Isolde (Gottfried von Straßburg), the pre-courtly Herzog Ernst, the lais by the Anglo-Norman poet Marie de France, the late medieval alliterative romance Sir Gawain and the Green Knight, or of the anonymous early modern German prose novel Fortunatus (1509). Courtly protagonists commonly traverse bodies of water (Konrad von Würzburg, Partonopier und Meliur, ca. 1290; Mai und Beaflur, ca. 1290; Boccaccio's Decameron, ca. 1350), but the narrators hardly ever pay any attention to the practical aspects of the voyage itself, such as food supplies, accommodations, entertainment, hygiene, or weather conditions. Granted, the experience of being victim of a shipwreck has mattered significantly in many medieval narratives (Classen, "Storms"). The fifteenth-century South-Tyrolean poet Oswald von Wolkenstein (1376/77-1445) includes many references to his numerous travels all over the then known world, and he even mentions that in his youth he was forced to serve on a galley, pulling oars (Oswald, K1. 18), but he provides only impressionistic glimpses into his checkered past and ignores most of the realistic elements.

Consequently, travel in those literary accounts mostly constitutes an abstract notion of moving from one place to another, while the travel itself with all of its challenges and problems remains an elusive, irrelevant, negligible aspect because only the departure and the arrival matter.

Marco Polo (1254-1324), the most famous traveler, relates countless aspects characterizing the eastern world, but he operates more like an economist and fabulist, as a historian and a merchants since he mostly abstains from providing concrete details of the travel itself in material terms (Classen; Schmitz-Esser, "Travel"; Conklin Akbari and Ianucci). As an observer of the foreign world, he consistently pursues an external perspective, and barely mentions his own travel experiences in specific terms, which is rather typical of many other contemporary travelogue authors, such as Odorico da Pordenone (ca. 1265-1331; cf. Schmitz-Esser, "Oderich").

\section{Pilgrimage: Religious Tourism}

The biggest travel throughout the pre-modern world was always the voyage to the Holy Land, mostly departing ultimately from Venice and crossing the eastern Mediterranean. The Crusades, by contrast, were a military version of this operation, replacing the fairly simple goal of visiting the holy sites, praying, gaining indulgence, and remission of sins, and all this combined with an aggressive approach intended to colonize the lands formerly occupied by Arab Muslims and to create new Crusader kingdoms. Even though the first Crusade was actually very successful, with the fall of Jerusalem to the Christian invaders in 1099, the subsequent decades and then the following centuries witnessed a rather contorted, torturous, ultimately catastrophic outcome, with the last Christian fortress, Acre, being re-conquered by the Muslim Mamluks in 1291 (Holt).

However, the Holy Land did not lose its profound appeal for Christian pilgrims as a consequence of Muslim rule there after the last Christian foothold had to be abandoned. The military efforts were subsequently replaced by religious tourism, as mirrored by virtually hundreds of pilgrimage accounts, dating from the fourth through the seventeenth century (Taylor and Craig; Herbers and Lehner 2014 and 2016). In fact, religious pilgrimage to Israel and Palestine has not come to any closure even today, especially because the historical foundation of Christianity is grounded in those lands. The conflict among the three world religions, however-Judaism, Islam, and Christianity-continues to have a huge impact on world politics until the very present, so a small sliver of land in the eastern Mediterranean proves to be the source of massive global conflicts even in the twenty-first century because the representatives of those three religions compete against each other over who holds the better stake in that Holy Land, or the higher authority

\section{THE WitNESS OF FELIX FABRI: A WEALTH OF INFORMATION}

While the larger historical, cultural, religious, and also art-historical aspects have been discussed already from many different perspectives, here I want to turn my attention to some of the very practical aspects of voyage in the late Middle Ages. Even though most travelogue authors refrained from going into details, and were obviously content with profiling only the global issues involved in such a voyage, mostly from Venice to Acre, Jaffa, or Ramla (Hahn), some of them were much more interested in conveying even minute details. Felix Fabri was one of those who spent much of his time writing about the ordinary, everyday-situations and illuminating the practical experiences most of the pilgrimage travelers had to go through (Wiegandt). 
This late medieval travel author has already been recognized for a long time as a most vivid testimony from the late fifteenth century who informed his audience in a most detailed fashion and paid much attention to every conceivable aspect of this kind of global travel (Hahn, 210-20). Even though recent scholars have emphasized more than previously the fictional, or simply narrative character of many of those pilgrimage accounts (Legassie), Fabri's efforts to be as realistic and specific as possible still deserves closer attention. Much more than virtually anywhere else, Fabri's Evagatorium emerges as a unique source for the material conditions that every traveler had to deal with.

Even if he might have exaggerated some of his observations and comments, at times closely following his learned sources, such as Pliny the Elder, Hrabanus Maurus, or Albertus Magnus, his report still proves to be most valuable for a close-up analysis of what travel, especially a voyage down the Adriatic Sea and through the eastern Mediterranean, meant in concrete terms. Subsequently I will examine carefully what information he relates about the actual conditions of the sea voyage and how the individual traveler experienced the travel in most crowded conditions on the ship on its way from Venice to the Holy Land. While other scholars have already discussed his meticulous world view, his precise geographical description, his detailed information about the various cities that he visited, such as Venice, and his impressive engagement with the foreign cultures and people in the Holy Land (Wiegand; Classen, "Encounters"; Reichert and Rosenstock, ed.), his extensive account also sheds most relevant light on the actual conditions on board of a ship at the end of the fifteenth century. Here we face a surprising research desideratum, maybe because most scholars have focused primarily on Fabri's religious and cultural experiences, but not on the data that he provides at great length about the daily aspects on a ship.

\section{Felix FABRI'S BIOGRAPHY}

Let us first gain a better understanding of Fabri's biography, which in itself is impressively well known and documented in a meticulous fashion (see the bibliography and other information contained in the excellent German webpage: https://de.wikipedia.org/wiki/Felix_Fabri, last accessed on Nov. 8, 2018). Felix Fabri made more efforts than many other pilgrimage authors to reach various audiences with different levels of education, composing three separate accounts, one in Latin (Evagatorium in Terrae Sancta, Arabiae et Egypti peregrinationem, 1484-1488), one in German (Eigentliche beschreibung der hin vnd wider Fahrt zu dem Heyligen Land, also ca. 1484-1488; first printed in 1556), and one, also in German (Fabri, Sionpilger, 1492, original does not seem to have survived, copies were written in 1493, 1494, 1495), but destined for female readers in a convent who could not travel on their own and so had to rely on such pilgrimage reports which allowed them to follow the author from station to station, doing the prayers and meditating on the religious setting, reliquaries, saints, churches, and chapels (Fabri, Sionpilger), but not carrying out those rituals in reality, but virtually back home in their convent. That way they could obey their monastic vow of the stabilitas loci and yet concomitantly realize their dream of getting to the Holy Land and hence close to all those holy sites, even if only in proxy (Classen, "Imaginary Experience"). We know much about Fabri's life and works especially because he proves to have been a rather well-learned, and highly esteemed personality who left behind many documents reflecting himself and his works. He was born in 1437/1438 (some claim in 1441 or 1442) in Zürich, joined the Dominican Order in Basel on November 25, 1452 (not in 1472, as older scholarship sometimes opined), and was appointed as Lector and main preacher in the Dominican monastery of Ulm in 1477/1478 (or perhaps as early as 1468) (Hannemann).

He went on his first pilgrimage, which was probably also an official business trip for his convent, in 1468 to Aachen (west of Cologne), and then he visited Rome in 1476, Colmar in 1482, and Nuremberg in 1485 or 1486, also in an official function. In 1486 and 1487 he represented his Order at the Comitia Generalia in Venice. He undertook his first pilgrimage to the Holy Land in 1480, where he briefly and almost hastily, as he later commented himself, visited Jerusalem. Fabri returned on a second pilgrimage in 1483, which then included Jerusalem, the Sinai, and Egypt. Fabri died in Ulm on March 14, 1502 (Carls; Klingner, "Felix Fabri”).

The degree to which Fabri's account, Evagatorium (1484-1488; here quoted from the edition by Jean Meyers, 2013), at least in its abbreviated German version for popular consumption, Eigentliche beschreibung der hin und widerfarth zu dem Hl. Landt from 1484-1488, was popular can be confirmed by the fact that it was printed in Ulm even as late as in 1556 and 1557, then again in 
Frankfurt in 1584 and 1609 (Fabri). The Latin version, however, did not appear in print until the nineteenth century. The 1584 edition in German was included in Sigmund Feyrabend's highly successful anthology of pilgrimage accounts to the Holy Land, the Reyszbuch dess Heyligen Lands, which contained seventeen reports by German travel writers from the time between 1095 and 1573, and an excerpt from John Mandeville's Travels. The Reyszbuch was reprinted eleven times until 1704. By comparison, the most popular pilgrimage account by another German author was the one by Bernard von Breydenbach, whose Peregrinatio in Terram Sanctam was initially printed in Latin by Peter Schöffer in Mainz in 1486, which was reprinted twelve times between 1486 and 1522, and which was quickly translated into German, Dutch, French, and Spanish (Klingner, "Bernhard").

Insofar as Fabri's first pilgrimage seems to have been fairly rushed and too compressed to give a full sense of the religious experience in the Holy Land, Fabri prepared himself thoroughly for the second voyage and read everything available to him, such as the itineraries of Jerome, Burchard, Arculf, Ludolph of Suchem, and others, apart from many other learned treatises (e.g., Pliny). The extensive account resulting from that pilgrimage documents the extent of his pre-departure planning and studying and the post-travel reflections and critical analysis of his notes and documents. Two members of this pilgrimage tour, Bernard von Breydenbach, Canon of Mainz, and the Franciscan Paul Walther of Guglingen, also wrote travelogues (see above). Nevertheless, the degree to which Fabri added personal comments, included anecdotes about his travel experience, and interesting information about many different aspects pertaining to the daily life in the exotic countries, makes his account considerably stand out head above shoulder of the one by Breydenbach and most other contemporaries (Weiss).

\section{Felix Fabri's Detailed Report about His Pilgrimage}

Fabri's Evagatorium proves to be such a voluminous and detailed account that we could approach it from many different perspectives, examining late medieval travel conditions, world perceptions, religious practices, use of foreign languages, the exchanges among people from different cultures, and food items (Classen, "Encounters," 93-120). Consequently, as to be expected, Fabri offers a wealth of information also about the ordinary experience for pilgrims on the ship transporting them from Venice to the Holy Land. Following, I will examine the data provided here and discuss the concrete conditions as outlined by this author.

As it will turn out, the Evagatorium can be regarded as a virtual quarry of cultural, material, political, economic, religious information. Since Fabri traveled twice to the Holy Land, and since he studied all the available literature on pilgrimage especially before his second departure, his long account from 1483 can serve as a powerful mirror of what most travelers probably experienced. But he did not simply project a generic comment, but carefully differentiated the situation for the various social classes, professions, and genders. Until today, after all, money has always profoundly determined the level of comfort and luxury which a pilgrim/traveler could expect to receive.

While in Venice, Fabri and his companions traveled around a lot to visit the various churches or monasteries, but those trips were, as they are today, only very short in distance and did not require any special accommodations. Traversing the Adriatic Sea and then the eastern Mediterranean, by contrast, constituted considerable challenges for all pilgrims during the pre-modern era, some of which other authors also mention, such as the payment to the ship captain, the long travel route, securing food for the entire trip, and the dangers of bad weather and sea pirates. Fabri, however, goes much more into details about the daily conditions and thus provides us with a stunning tableau of an extraordinary kind hardly ever matched or paralleled by other contemporary writers.

Before he turns his attention to the situation for the pilgrims themselves, Fabri outlines the generic knowledge about the various bodies of water that have to be crossed on the way to the Holy Land, based on his intensive studies of the relevant research literature or previous travelogues (554-70). Next, the author discusses the various types of dangers associated with the sea, both pertaining to seasickness and to piracy, to shipwreck and the constant danger of falling off the ship and drowning. Next, Fabri examines the social hierarchy on a ship, considering the chain of commands, which confirms how much he attentively studied what was going on during the voyage and who had the final say in all the decisions that have to be made all the time to maintain the ship and to keep it on course. This is followed by a section on the size and type of the ship that they are using, and the social 
arrangements of all people on board since there must be order, separating men and women from each other, the captain from the sailors, married people from the rest, etc. He also details what languages the galley slaves speak, bemoaning at the same time their miserable destiny (404).

Since the group of travelers consists of a fairly large number of individuals, conflicts easily erupt and require judgments, for which a judge on board of the ship is called upon (406-08). For Fabri, more important proved to be the question how he and other clerics could carry out their regular liturgy and read mass, even under the difficult circumstances of traveling on a ship (408-24). The case of death during the voyage constituted a difficult issue, but Fabri outlines in clear details how the body was taken care off, either through a sea burial, or through an interment in a near-by cemetery, if available or accessible (cf. Schmitz-Esser, Der Leichnam, 38-40, 46-47; without reference to Fabri, however).

Another important aspect, normally not even mentioned in most other pilgrimage accounts, pertained to the question how to spend the empty time since there was nothing really to do for the travelers except to study the world around them, to read, play games, to write, to sleep, to eat and drink, to play a music instrument, to sing, to chat, and, which Fabri emphasizes with disgust, to chase down vermin, such as rats and lice (426-28). The author also tries to psychologize the situation by analyzing the major mood swings among the travelers, maybe depending on the weather, or the duration of the voyage (428).

Due to the very limited space on a galley, and considering the large number of pilgrims on board, it was obviously a very difficult task to provide enough room for everyone during meal times. Consequently, as we learn from Fabri, individual groups had to take turns and rush through their dinner, for instance, making it possible for the next to receive the food (430-32). This applied, however, only to the men, while the women, obviously always in minority, received their meals as one group at a special location (432). The common food and drinks served must have been drab and tasteless, if not even rotten, but any traveler could pay the cooks extra to receive higher quality (432), which seems like a common practice until today, especially on airplanes. As Fabri emphasizes, "Domini milites abhominantur cibum patroni et magnam dant cocis pecuniam pro singulari cibo" (432; the nobles detest the food given by the ship captain and give much money to the cook for special food). Meat, for instance, regularly comes from dying or dead animals, making the meal virtually toxic for the consumer.

But what happens at night, and how do the pilgrims find their rest? As far as I can tell, Fabri is the only late medieval author considering these questions and providing detailed information (434). No one on board can avoid being surrounded by a dense crowd and huge noise, with so many people crammed together in very narrow quarters. Many squabble over small infractions, encroachments, disturbances, or insults, which causes a huge tumult. Although these are all pilgrims who should observe good Christian values, Fabri exposes their human nature, that is, their aggression and mean spirit, attacking each other over minuscule matters. As is always the case in large groups of people that have to find their night rest in one shared room, some do not go to sleep immediately but keep their lights on and chat with others, disturbing the entire crowd.

The author admits that he has seen cases when people throw the content of their night pots on those lamps to extinguish them, which creates even further disputes and quarrels: "magna litigia" (434). Only the energetic effort by some resolute men succeeds in calming everyone down, but, as Fabri then also mockingly comments, the problems tend to be inflamed because there are "ebriosi Flammingi" (434; drunk Flemish). Full of pity, Fabri comments, regarding the quieter pilgrims who back home tend to live all by themselves, how difficult it constantly proves to be for them to find any rest during the night. No one can turn around on his sleeping bunk without touching his neighbor, and because of the doors being shut, the air is hot and smelly, and everybody is bothered badly by lice, mice, and rats (434).

Fabri himself comments that staying in those sleeping quarters appeared to him like a prison cell, so he quietly got up and left them, moving to the upper deck for fresh air and calmness because many of the pilgrims suffer from nightmares and utter loud screams or speak in their sleep (436). Many times, the horses and mules are stabled above the miserable people, who are thus constantly disturbed in their sleep by the noise of the animals' hooves, not to mention the loud noise from the sea itself, the sailors, and many other sources. The pilgrims have to suffer constantly and experience a rather miserable time, especially because every person has his/her own natural needs to relieve himself, as 
the next chapter illustrates rather drastically. Every traveler has a movable urinal next to his bed for urine and vomit (436), but it seems unavoidable that many of those are tipped over when someone, in the darkness of the night, needs to leave the room, which leads to insufferable stench, "fetor intolerabilis" (436). Not shy of describing also the natural need to relieve oneself from feces, he discusses the set-up for this purpose on the edge of the ship, but the large crowd of travelers brings it about that everyone has to line up and wait until it is their turn, which causes additional strife and anger. We are not informed about how the people manage to clean themselves; instead, Fabri only offers a comparison to a similar situation when people line up in front of a confessional and get angry when an individual talking to the priest takes too long (438). It is a very rare incident in medieval narratives to be informed in such a realistic fashion about the basic need to defecate and how this business is handled on a ship (generally, see Wagener, ed.; for toilets in monasteries, see Tuten).

Going into further details, Fabri outlines the enormous difficulties for an individual who might want to leave the sleeping quarter to attend to the toilets because the space is so narrow, and one has to watch people resting everywhere (438). When storms rage, the waves tend to roll over the ship, drenching everyone on the upper deck (probably below as well). Many of the pilgrims therefore, when they have to relieve themselves, simply remove all of their clothing, abandoning all shame and embarrassment out of simple practicality. Others relieve themselves in the sleeping quarters, fully exposed to everyone present, which is regarded as somewhat scandalous, unless the person suffers from sickness and is thus excused (438). Within the same context, Fabri warns especially to guard oneself against constipation and diarrhea, "quia utrumque perniciosum est nauiganti" (438; because both are dangerous to the voyagers). In order to prevent any of those problems, the well-advised pilgrim should use the toilet at least three or four times a day (440). The author also admonishes his reader, the future pilgrim, to bring with him several sets of clothing because those who do not watch this advice have to wear the same day-in and day-out, walking around covered in sweat and smelling badly. Men ought to pay close attention to their beards and wash it regularly to get rid of lice; otherwise they would have to shave themselves, which would bring shame upon them (440). Alternatively, as he also points out, it would not be shameful if one let's another person examine the beard carefully and clean it from lice. It also would be necessary to wash one's shirts regularly.

While many of those problems amount to serious difficulties for the pilgrim, the real bother emerges when the neighbor turns out to be "inuidiosum, impacientem, litigiosum, inquietum, iracundum et immundum" (440; envious, impatient, litiginous, restless, irascible, and dirty). But Fabri insists that he is not talking in theoretical terms; instead, he himself has experienced all that: "Expertus sum huius mali penam" (440; I myself am an expert of such torture). Hence, we can also trust him in his drastic descriptions of the many different bad odors (442), of the plague with mice and rats (444), which rummage through everything and make life difficult on the ship. By the same token, Fabri comments with relief that all the usual venomous critters on land, such as snakes, scorpions, or spiders, cannot be found on a ship because of the water that holds them back (444).

However, one of the greatest dangers for the traveler consists of the untrustworthy sailors who steal anything they can put their hands on (446), although they are not at all permitted to enter the pilgrims' sleeping quarters for that very reason. By the same token, walking around at night outside on the deck, for instance, would also awaken suspicion by the sailors, who do not trust the pilgrims either (452). Jumping into the sea to take a bath and thus to increase one's cleanliness would be a great danger, even for the best swimmers because of the currents (448). In the harbor, when the ship is taking a break during the journey, it would be dangerous to walk around by oneself because pirates could easily kidnap the unfortunate individual and sell him into slavery (454). At the same time, the travelers are strongly advised to stay away from the brothels that can be found in every harbor (454), a topic that had alerted Fabri's attention already earlier (180).

\section{CONCLUSION}

There would be many other aspects to consider, drawing from Fabri's highly lively, detailed, informative, and also a bit dramatizing account. We would not need to question the veracity of his narrative, as sensational as it might sound at time, horrifying and terrifying the readers back home who are thus impressed about the hardship which the pilgrim has to go through, especially during the voyage. As much as Fabri might occasionally exaggerate, here we discover one of the best, most specific reports about the actual conditions on a galley taking Christian pilgrims from Venice to the 
Holy Land. We have to consider, however, that he describes the conditions from the perspective of a lowly individual who does not enjoy the luxury of a comfortable voyage due to the high-ranking class. Nobles certainly fared considerably better, as we have already seen, especially because they were wealthy enough to pay the cooks for better food and wine, whereas the ordinary traveler had to live by what he received as his apportioned meals and drinks.

As unpleasant as some of the accounts might be, especially when Fabri explains in detail the practice of relieving oneself while on ship, as important his comments prove to be because hardly any other medieval travelogue author, not to speak of poets or composers of romances, has ever offered us such realistic insight into the day-to-day conditions of a voyage at the end of the fifteenth century. We would actually be hard pressed if we tried to identify a similarly well-informed and detail-oriented narrative in the modern era. In this sense, Felix Fabri proves to be a major author who shed significant light on most basic but truly critical aspects relevant for all pilgrims traversing the sea. Many other scholars have already examined the way how medieval/late medieval writers projected their world and how they visualized those images and perceptions in their texts in scientific, allegorical, moral, ethical, political, and spiritual terms (Bleuler and Klingbeil; Classen, ed., Travel).

We know much today about the travel routes pursued by the late Middle Ages, the types of ships used, the costs of the voyage, the food supplies that had to be purchased before the departure, and the dangers of the travel across pirate-infested sea worlds, where also Turks could capture a ship and enslave the travelers. But if we ignore the daily routine, the need for every individual to ingest, digest, and to expel the refuse, as closely discussed by Fabri, we cut ourselves short and do not gain a full understanding of human existence while on a voyage to the Holy Land by the end of the fifteenth century. His Evagatorium thus proves to be an extraordinarily fortunate and productive case where all that basic information and even much more comes to the fore and matters centrally, even for pilgrims on their way to the most holy sites in Christianity.

\section{REFERENCES}

[1] Bleuler, Anna Kathrin, and Anja-Mareike Klingbeil, ed. Welterfahrung und Welterschließung in Mittelalter und Früher Neuzeit. Interdisziplinäre Beiträge zu Mittelalter und Früher Neuzeit, 5. Heidelberg: Universitätsverlag Winter, 2016.

[2] Brefeld, Josephie. A Guidebook for the Jerusalem Pilgrimage in the Late Middle Ages: A Case for Computer-Aided Textual Criticism. Middeleeuwse Studies en Bronnen, XL. Hilversum: Verloren, 1994.

[3] Carls, Wieland, in Felix Fabri, Die Sionpilger, ed. Wieland Carls. Texte des späten Mittelalters und der frühen Neuzeit, 39. Berlin: Erich Schmidt, 1999.

[4] Classen, Albrecht, ed. East Meets West in the Middle Ages and Early Modern Times: Transcultural Experiences in the Premodern World. Fundamentals of Medieval and Early Modern Culture, 14 (Berlin and Boston: Walter de Gruyter, 2013).

[5] Classen, Albrecht. "Encounters Between East and West in the Middle Ages and Early Modern Age: Many Untold Stories About Connections and Contacts, Understanding and Misunderstanding," East Meets West in the Middle Ages and Early Modern Times: Transcultural Experiences in the Premodern World, ed. Albrecht Classen. Fundamentals of Medieval and Early Modern Culture, 14 (Berlin and Boston: Walter de Gruyter, 2013), 1-222.

[6] Classen, Albrecht. "Imaginary Experience of the Divine: Felix Fabri's Sionpilger - Late-Medieval Pilgrimage Literature as a Window into Religious Mentality," Studies in Spirituality 15 (2005): 109-28.

[7] Classen, Albrecht. "Roads, Streets, Bridges, and Travelers." Handbook of Medieval Culture: Fundamental Aspects and Conditions of the European Middle Ages, ed. id. Berlin and Boston: Walter de Gruyter, 2015, vol. 3,1511-34.

[8] Classen, Albrecht. "Storms, Shipwrecks, and Life-Changing Experiences in Late Medieval German Literature. From Oswald von Wolkenstein to Emperor Maximilian.” Oxford German Studies 43.3 (2014): 212-28.

[9] Classen, Albrecht, ed. Travel, Time, and Space in the Middle Ages and Early Modern Time:

[10] Explorations of World Perceptions and Processes of Identity Formation. Fundamentals of Medieval and Early Modern Culture, 22. Berlin and Boston: Walter de Gruyter, 2018.

[11] Conklin Akbari, Suzanne and Amilcare Iannucci, ed. Marco Polo and the Encounter of East and West (Toronto: University of Toronto Press, 2008).

[12] Dorninger, Maria E. "Travelogues." Handbook of Medieval Studies: Terms - Methods - Trends. Ed. Albrecht Classen. Berlin and New York: Walter de Gruyter, 2010, vol. 1, 2102-17. 
[13] Fabri, Felix. Les errances de frère Félix, pèlerin en Terre sainte, en Arabie et en Egypte, 1480-1483, texte latin, traduction, introduction et notes sous la direction de Jean Meyers et Michel Tarayre. Paris: Classiques Garnier, 2013.

[14] Fabri, Felix. Evagatorium in Terrae Sanctae, Arabiae et Egypti peregrinationem, ed. Conrad Dietrich Hassler. 3 Vols. Bibliothek des Literarischen Vereins in Stuttgart, 2, 3, 18. Stuttgart: Literarische Verein, 1843-1849.

[15] Fabri, Felix. Die Sionpilger, ed. Wieland Carls. Texte des späten Mittelalters und der frühen Neuzeit, 39. Berlin: Erich Schmidt, 1999.

[16] Denke, Andrea. Konrad Grünembergs Pilgerreise ins Heilige Land: Untersuchung, Edition und Kommentar. Stuttgarter Historische Forschungen, 11. Cologne, Weimar, and Vienna: Böhlau, 2011.

[17] Hahn, Christian. Deutsche Reiseberichte. Europäische Reiseberichte des späten Mittelalters, 1. 2nd rev. and expanded ed. Kieler Werkstücke. Reihe D, 5. Frankfurt a. M., Berlin, et al.: Peter Lang, 2001.

[18] Hannemann, Kurt, "Fabri, Felix," Die deutsche Literatur des Mittelalters: Verfasserlexikon, ed. Kurt Ruh et al. Vol. 2. Berlin and New York: Walter de Gruyter, 1980, 682-89.

[19] Harff. Rom - Jerusalem - Santiago: Das Pilgertagebuch des Ritters Arnold von Harff (1496-1498). Nach dem Text der Ausgabe von Eberhard von Groote übersetzt, kommentiert und eingeleitet von Helmut BrallTuchel und Folker Reichert. Cologne, Weimar, and Vienna: Böhlau, 2007.

[20] Herbers, Klaus, and Hans Christian Lehner, ed. On the Road in the Name of Religion: Pilgrimage as a Means of Coping with Contingency and Fixing the Future in the World's Major Religions. Beiträge zur Hagiographie, 15. Stuttgart: Franz Steiner Verlag, 2014.

[21] Herbers, Klaus, and Hans Christian Lehner, ed. On the Road in the Name of Religion II: Ways and Destinations in Comparative Perspective - Medieval Europe and Asia. Beiträge zur Hagiographie, 17. Stuttgart: Franz Steiner Verlag, 2016.

[22] Holt, Andrew. "Crusades Historiography."Handbook of Medieval Studies: Terms - Methods - Trends. Ed. Albrecht Classen. Berlin and New York: Walter de Gruyter, 2010, vol. 1, 379-92.

[23] Klingner, Jacob. "Bernhard von Breidenbach." Deutsches Literatur-Lexikon: Das Mittelalter, ed. Wolfgang Achnitz. Vol. 3: Reiseberichte und Geschichtsdichtung. Berlin and Boston: Walter de Gruyter, 2012, 915-22.

[24] Klingner, Jacob. "Fabri, Felix.” Deutsches Literatur-Lexikon: Das Mittelalter, ed. Wolfgang Achnitz. Vol. 3: Reiseberichte und Geschichtsdichtung. Berlin and Boston: Walter de Gruyter, 2012, 922-35.

[25] Legassie, Shayne Aaron. The Medieval Invention of Travel. Chicago and London: The University of Chicago Press, 2017.

[26] Oswald. Die Lieder Oswalds von Wolkenstein, ed. Karl Kurt Klein. 4th, thoroughly rev. ed. by Burghart Wachinger. Altdeutsche Textbibliothek, 55. Berlin and Boston: Walter de Gruyter, 2015.

[27] Reichert, Folker, and Alexander Rosenstock, ed. Die Welt des Frater Felix Fabri. Weißenhorn: Anton H. Konrad Verlag, 2018.

[28] Schmitz-Esser, Romedio. Der Leichnam im Mittelalter: Einbalsamierung, Verbrennung und die kulturelle Konstruktion des toten Körpers. Mittelalter-Forschungen, 48. Ostfildern: Jan Thorbecke, 2014; sec. ed. 2016.

[29] Schmitz-Esser, Romedio. "Oderich von Pordenone, Asienreiseberichte des Mittelalters und ihre 'causa scribendi'." Mediaevistik 30 (2017): 147-75.

[30] Schmitz-Esser, Romedio. "Travel and Exploration in the Middle Ages." Handbook of Medieval Culture: Fundamental Aspects and Conditions of the European Middle Ages, ed. id. Berlin and Boston: Walter de Gruyter, 2015, vol. 3, 1680-1704.

[31] Taylor, Larissa and Leigh Ann Craig, et al., ed. Encyclopedia of Medieval Pilgrimage (Leiden and Boston: Brill, 2010).

[32] Stabel, Peter and Inneke Baatsen. "At Home and on the Road: Comparing Food Cultures in the Medieval Low Countries." Travel, Time, and Space in the Middle Ages and Early Modern Time: Explorations of World Perceptions and Processes of Identity Formation. Ed. by Albrecht Classen. Fundamentals of Medieval and Early Modern Culture, 22. Berlin and Boston: Walter de Gruyter, 2018, 331-58.

[33] Tuten, Belle S. "The Necessitas Naturae and Monastic Hygiene." Bodily and Spiritual Hygiene in Medieval and Early Modern Literature: Exploration of Textual Presentations of Filth and Water, ed. A. Classen. Fundamentals of Medieval and Early Modern Culture, 19. Berlin and Boston: Walter de Gruyter, 2017, 129-47.

[34] Wagener, Olaf, ed. Aborte im Mittelalter und der Frühen Neuzeit: Bauforschung - Archäologie Kulturgeschichte. Petersberg: Michael Imhof Verlg, 2014. 
[35] Weiss, Gerhard. "The Pilgrim as Tourist: Travels to the Holy Land as Reflected in the Published Accounts of German Pilgrims Between 1450 and 1550." The Medieval Mediterranean: Cross-Cultural Contacts, ed. Marilyn J. Chiat and Kathryn L. Reyerson. Medieval Studies at Minnesota, 3. St. Cloud: North Star Press of St. Cloud, 1988, 119-31.

[36] Wiegand, Herbert. Felix Fabri: Galeere und Karawane: Pilgerreise ins Heilige Land, zum Sinai und nach Ägypten 1483. Alte abenteuerliche Reiseberichte. Stuttgart, Vienna, and Bern: Ed. Erdmann, 1997.

[37] Wiegand, Hermann. Felix Fabri, Galeere und Karawane: Pilgerreise ins Heilige Land, zum Sinai und nach Ägypten 1483. Bearbeitet und mit einem Nachwort. versehen von Herbert Wiegandt. Alte abenteuerliche Reiseberichte. Stuttgart, Vienna, and Bern: Edition Erdmann, 1996.

\section{AUTHOR's BIOGRAPHY}

Dr. Albrecht Classen is University Distinguished Professor of German Studies at The University of Arizona, Tucson. He has published close to 100 scholarly books and ca. 670 articles on medieval and early modern literature, culture, history, religion, gender issues, and ecocriticism. In his most recent books he has focused on the themes of travel, ecocriticism, women's issues, love and marriage, magic and magicians, hygiene, and death. He has received numerous awards for teaching, research, and teaching, especially the German Bundesverdienstkreuz am Bande (2004), the 2009 Five Star Faculty Award, the 2012 Carnegie Foundation Professor of the Year Award, and the 2015 Excellence in Academic Advising Faculty Advisor Award. He is the editor of the journals Mediaevistik and Humanities Open Access. Dr. Classen has been guest professor at many universities all over the world (South Korea, Japan, Australia, Poland, Finland, Germany, Great Britain, Spain, Mexico, etc.).

Citation: Albrecht Classen. "Travel by Ship in the Late Middle Ages - Felix Fabri's Pilgrimage Account as a Meticulous Eye-Witness Report”. International Journal of History and Cultural Studies (IJHCS). vol 4, no. 4, 2018, pp. 42-50. doi: DOI: http://dx.doi.org/ 10.20431/2454-7654.0404003.

Copyright: (C) 2018 Authors. This is an open-access article distributed under the terms of the Creative Commons Attribution License, which permits unrestricted use, distribution, and reproduction in any medium, provided the original author and source are credited. 